\title{
CASE STUDIES OF FAMILY EXPRESSED EMOTION FOR PERSONS LIVING WITH SCHIZOPHRENIA IN DELTA STATE OF NIGERIA
}

(Received: 30 June 2008; accepted 27 May 2009)

\begin{abstract}
This study is aimed at assessing family expressed emotions as a predictor of health status of family members living with schizophrenia as well as identifying some characteristics for high or low emotions of family members towards a 'sick' member. There were thirty-one families with members suffering from schizophrenia as diagnosed by psychiatrists (using DSM-IV-TR) in government owned hospitals. They were judgmentally sampled with the assistance of social workers. The instrument for gathering data was a validated modified Camberwell Family Interview (CFI) schedule reflecting three major areas: Hostility, Critical comments and Over-involvement of expressed emotions of family members. The procedure was using trained research assistants from the area to conduct these interactive sessions in their lingua franca. The data generated was subjected to qualitative analysis which shows that out of the 31 families studied, 25 or $80.65 \%$ had high expressed emotions while six families or $19.35 \%$ had low expressed emotions. However, only five 'sick' members had not experienced a relapse since the first treatment and discharge. Seven 'sick' members were vagrant of the 25 high expressed emotion families. The study revealed that expressed emotions significantly determine the number of relapses of the member living with schizophrenia; that the gender of a 'sick' member does in fact determine the level of expressed emotion from family members. The study also revealed that the poverty of families or shame for families from low and high socio-economic backgrounds respectively are motives for emotions expressed. A model of family therapy was proffered.
\end{abstract}

Keywords: Nigeria, Camberwell Family Interview, expressed emotions, family care, predictor, relapse, schizophrenia

* Christian Ewhrudjakpor, Department of Sociology, Delta State University, P.M.B 1, Abraka, Delta State, Nigeria; acadchris@yahoo.com. 
Fallstudien zu von Familienmitgliedern geäußerten Gefühlen bei Menschen mit Schizophrenie im nigerianischen Bundesstaat Delta: Ziel der Studie ist es, zu untersuchen, inwieweit von Familienmitgliedern geäußerte Gefühle als Prädiktoren für den Gesundheitszustand ihrer mit Schizophrenie lebenden Familienangehörigen geeignet sind. Eine weitere Zielsetzung ist es, bestimmte Charakteristika von starken bzw. schwachen Gefühlen zu bestimmen, die die Familienmitglieder ihrem „kranken“ Familienangehörigen gegenüber äußern. Die Untersuchung umfasst einunddreißig Familien, bei denen in staatlichen Krankenhäusern tätige Psychiater (unter Verwendung der DSM-IV-TR-Diagnostik) an Schizophrenie leidende Familienmitglieder registriert haben. Die theoretisch begründete Auswahl der Stichprobe wurde unter Einbeziehung von Sozialarbeitern durchgeführt. Für die Datenerhebung wurde ein kontrollierter und modifizierter Camberwell Family Interview (CFI) Fragebogen verwendet, der auf drei Hauptbereiche fokussiert: feindselige Gefühle der Familienmitglieder, kritische Bemerkungen und die Äußerung von extreme Beteiligung verratenden Gefühlen. Während der Durchführung wurden die interaktiven Treffen von aus dem jeweiligen Gebiet stammenden ausgebildeten Forschungsassistenten in ihrer gemeinsamen Sprache geleitet. Die erhobenen Daten wurden einer qualitativen Analyse unterzogen. Diese zeigte, dass für 25 (80,65\%) der einbezogenen 31 Familien die Äußerung starker Gefühle und für die übrigen sechs Familien $(19,35 \%)$ die Äußerung schwacher Gefühle kennzeichnend war. Gleichzeitig gab es nur fünf „kranke“ Familienmitglieder, bei denen nach der ersten Behandlung bzw. der Entlassung kein Rückfall (relapse) erfolgt wäre. Sieben „kranke“ Familienmitglieder haben ihre durch die Äußerung starker Gefühle gekennzeichnete Familie verlassen. Die Untersuchung machte deutlich, dass die geäußerten Gefühle in großem Maße das Rückfallrisiko der Familienangehörigen mit Schizophrenie bestimmen und dass das Geschlecht die Intensität der von den Familienangehörigen geäußerten Gefühle bestimmt. Die Studie zeigte auch, dass bei Familien mit einem gering geachteten gesellschaftlichen bzw. wirtschaftlichen Hintergrund Armut die Grundlage für die geäußerten Gefühle bildet, bei Familien mit einem hoch geachteten Hintergrund jedoch Beschämung. Die Studie bietet ein Familientherapie-Modell an.

Schlüsselbegriffe: Nigeria, Camberwell Family Interview, geäußerte Gefühle, Familienhilfe, Prädiktor, Relapse, Schizophrenie

\section{Introduction}

Families are a huge determinant or significant predictor of the course of illnesses that stigmatize, particularly schizophrenia (BREWIN et al. 1991). This is because families of people living with schizophrenia suffer a great deal from social prejudices and discriminations (OSHISADA 2006). One of the main reasons for relapse in schizophrenia is family or care givers expressed emotion. The expressed emotion can be high or low, which may be adjudged by a taped interview such as the 'Camberwell Family Interview' (CFI). The three main attitudes relating to expressed emotion in the 'Camberwell Family Interview' schedule are known as hostile, critical, and emotional overinvolvement that relatives may have toward a family member with a form of schizophrenia. These attitudes of the relatives determine the course of the illness after treatment and discharge. The relatives influence the outcome of the disorder through negative comments and nonverbal actions. This negative attitudinal posture from loved ones does not help the family member to improve the state of their health (VAUGHN \& 
LEFF 1976). The family's criticism makes the relative feel that everything is their fault and they cannot make things right so they feel helpless, and consequently suffer mental breakdown (HoOley \& RiCHTERS 1995; BUTZLAFF \& HOOLEY 1998; WENDEL et al. 2000; ORHAGEN \& ELIA 1991). They have nowhere to turn to for help because of the family's negativity; therefore, they relapse back into the same thing that the family is being critical about (LOPEZ et al. 2004). This brings to the fore the inability of families to effect protective custody of their mentally disturbed member (RÖSSLER et al. 1996; WeISMAN et al. 1998; BULLOCK et al. 2002; MATTEW \& JAN 2007). This study is aimed at assessing family expressed emotions as a predictor of the wellbeing of member(s) living with schizophrenia. They are sometimes characterized by a variety of symptoms including, but not limited to, loss of contact with reality. They include one of four forms: residual, catatonic, disorganized and undifferentiated. Although the family is recognized as an important resource in the case of the mentally ill in Nigeria; similarly to many developing countries, not many studies have been done on the topic in Nigeria. It is against this background that this study was conducted.

Certain as yet unidentified characteristics of some family members may place them at a greater risk for developing critical emotions when they are exposed to the disturbed behaviour of the relative with schizophrenia or stigma from the community because of the mentally ill member in the house. Expressed emotion reflects an interaction of trait-like factors, cultural and socio-economic conditions of family members. This study is set out to find a scientific interpretation of family expressed emotions as a predictor or determinant of the course of illness of family members living with schizophrenia in Delta State of Nigeria. Its aim is also to identify some characteristics of family members that place them at a greater risk for developing high emotions towards behaviourally disturbed members of the household.

\section{Method}

\subsection{Study area}

The Federal Republic of Nigeria is the $10^{\text {th }}$ largest country in the world with a population of 140,003,542 people. Nigeria has 36 states with Delta State as one of the newest. Delta State where the study was carried out, was created on August 27, 1991, out of the defunct Bendel State. The 2006 census figure for Delta State is 4,098,391 representing $2.927 \%$ of the $140,003,542$ people of the Federal Republic of Nigeria ('Nigeria Census Figures 2006' 2007). With a total area of 16,475 square kilometres, the state is bordered on the North by Edo State, on the North-West by Ondo, on the East by Anambra and Rivers State and on the South by Bayelsa, while it has the Atlantic Ocean as its Western boundary. The state has 25 Local Government areas with Asaba as the administrative headquarters. The major language groups and ethnic nationalities in the state are the Urhobo, Ibo, (Ukwuani), Ijaw, Isoko, and Itsekiri. They have identical customs, beliefs and culture. The state has vast oil and gas deposits, the highest oil producing state in the oil-rich Niger Delta region, contributing 30\% to the 
oil revenue of Nigeria (WORGU 2000). Despite this perceived huge oil wealth, 70 million Nigerians earn below US\$ 1 per day. The Human Development Report (2000) ranked Nigeria among the 20 poorest countries in the world. The poverty that pervades the country is replicated in Delta State. The state has 44 hospitals, 7 of which have psychiatric facilities and services. There is no specialist psychiatric facility as is the case in the neighbouring Edo State with Uselu Psychiatric Hospital in Benin city and the Psychiatric unit of the University of Benin teaching hospital. These psychiatric facilities are also used for intensive in-patient care for people suffering from schizophrenia from in Delta State.

\subsection{Instrument}

This research was conducted using a modified version of the Camberwell Family Interview (CFI) revised to be applicable to the lives of the people of Nigeria. The instrument was then validated with a known group method of construct validation, which yielded a validity score $(r=13.22 ; d f=14, p<0.05 ; r=0.86 ; d f=8, p<0.05)$, known group of families with members suffering schizophrenia.

The modified CFI was made up of two sessions ('A' and 'B'). Session 'A' was a discussion about the socio-demographics of the head of the family. This relates to: family type and size, socio-economic status and educational status. While session 'B' contains the interview, the interactive sessions and the observation items under the three sub-headings reflecting behaviour and emotions about family members living with schizophrenia. These sub-headings include: (a) Critical comments about family members, (b) Hostility, and (c) Emotional over-involvement. This modified CFI section 'B' contains 20 items weighted 2 marks each. Therefore, high expressed emotion is when the relative makes 20 or more critical comments or negative nonverbal reactions during the interview. Low expressed emotion is considered to be less than 20 critical comments or more than 20 positive remarks or nonverbal positive reactions. This interview is a way to watch verbal and nonverbal answers to make an accurate assessment. High expressed emotion involves more criticism, hostility and emotional over-involvement than low expressed emotion. It is assumed that family members high in expressed emotion cause relapse in the schizophrenic relative. Therefore, the stress from negative criticism and pity becomes a burden on the family member with schizophrenia and the only way to cope is relapse.

\subsection{Sampling technique/Sample}

The author used judgmental sampling technique to select families with persons living with schizophrenia. This is due to the objective of this study, the smallness of the study population, and the author's knowledge of schizophrenics. Permission was sought from the Chief Medical Directors of the seven government hospitals involved to get access to medical case files of persons suffering schizophrenia clinically diagnosed by 
Psychiatrist/ Physicians (using DSM-IV-TR). Then the names and addresses of these persons were collected with the assistance of social workers, the families were met and two dates arranged for interactive sessions with the family. This procedure generated a sample of 47 cases of people suffering schizophrenia living with their families. But only 31 agreed to participate in the Family Interactive sessions. The other 16 families refused participation due to the bereavement of a family member during the period or shame (despite all efforts to prove anonymity of the study).

\subsection{Procedure}

The type of study design used was the family interaction method through CFI sessions, which enables the researcher to identify the behaviour and emotionality towards members living with schizophrenia. In order to measure this expressed emotion, the family is interviewed to carefully watch their expressions and comments while answering questions. The author, as the principal investigator, and six other research assistants trained in the handling and coding of the CFI, conducted this study in locations determined by the case files across the state. There are two outcomes of the opinion of the relative(s): high expressed emotion or low expressed emotion. This is determined by the amount of critical comments made by the relative. The interview and interactive sessions help to find out if the house that the patient will live in after rehabilitation might contribute to the relapse. The second phase is the follow up period, which starts when the sick member is discharged; another CFI is conducted again with the treated member present.

Each CFI session was conducted by the author and trained research assistants who are from the community and can interpret the English Language in the dialect or lingua franca of the people. The research assistants were given financial assistance. A single CFI took 60-90 minutes. The author used a micro cassette recorder while assistants were taking notes during the CFI sessions with family members. The whole exercise to generate information from 31 households lasted for fourteen months, between February 2007 and March 2008.

\subsection{Data analysis}

The data was qualitative. All the tapes recorded from the interviews and interactive sessions (31 of them) from 31 families conducted before and after the discharge of patients were transcribed and compared with notes taken. There are two outcomes of the opinion of the relative: twenty-five families have high expressed emotions and six families have low expressed emotions after the first interview with the head of households and family members (see Table 1). This is determined by the amount of critical comments made by the relatives. A high expressed emotion is when the relative makes 20 or more critical comments or nonverbal negative reactions during the interview. Low expressed emotion was considered to be less than 20 critical comments or 20 
positive comments. Those who have high expressed emotions tend to be more negative than the ones who are low. The measure of expressed emotions here was indexed on a comparison of the low and high EE families using the number of relapse cases. Generally there is not much room for quantification (VAUGHN \& LEFF 1976; ORHAGEN $\&$ ELIA 1991). At the end of the follow-up period, Table 2 summarizes the course of patients' schizophrenia in relation to family expressed emotions.

Table 1

Summary of socio-demographics of heads of households (families) after the first phase of interviews $(N=31)$

\begin{tabular}{|c|c|c|c|c|c|c|}
\hline $\begin{array}{l}\text { Head of } \\
\text { household }\end{array}$ & $\begin{array}{c}\text { Marital } \\
\text { status }\end{array}$ & Family type & $\begin{array}{c}\text { Family size } \\
\text { (Average) }\end{array}$ & $\begin{array}{l}\text { Socio- } \\
\text { economic } \\
\text { status }\end{array}$ & $\begin{array}{l}\text { Educational } \\
\text { status }\end{array}$ & $\begin{array}{c}\text { Level of } \\
\text { expressed } \\
\text { emotion }(E E)\end{array}$ \\
\hline $\begin{array}{l}\text { Male: } 9 \\
\text { Mean age: } \\
46.25\end{array}$ & $\begin{array}{l}\text { Married: } 9 \\
\text { Not mar- } \\
\text { ried: } 0\end{array}$ & $\begin{array}{l}\text { Monogamy: } 9 \\
\text { Polygamy } 0\end{array}$ & $\begin{array}{l}\text { Husband \& } \\
\text { wife, plus } 3 \\
\text { children: } \\
5 \text { members }\end{array}$ & $\begin{array}{l}\text { High: } 7 \\
\text { Medium: } 0 \\
\text { Low: } 2\end{array}$ & $\begin{array}{l}\text { Tertiary insti- } \\
\text { tution: } 6 \\
\text { No education: } 3\end{array}$ & $\begin{array}{l}\text { Families with } \\
\text { high EE: } 5 \\
\text { Families with } \\
\text { low EE: } 4\end{array}$ \\
\hline \multirow[t]{2}{*}{$\begin{array}{l}\text { Female: } 22 \\
\text { Mean age: } \\
33.74\end{array}$} & Divorced: 4 & Single: 4 & $\begin{array}{l}\text { Family rela- } \\
\text { tions plus: } \\
5 \text { children: } \\
7 \text { members }\end{array}$ & Low: 4 & No education: 4 & $\begin{array}{l}\text { Families with } \\
\text { high EE: } 20\end{array}$ \\
\hline & Widow: 18 & Single: 18 & $\begin{array}{l}\text { Family rela- } \\
\text { tions plus } \\
3 \text { children: } \\
5 \text { members }\end{array}$ & $\begin{array}{l}\text { High: } 2 \\
\text { Medium: } 6 \\
\text { Low: } 10\end{array}$ & $\begin{array}{l}\text { Tertiary insti- } \\
\text { tutions: } 4 \\
\text { Primary edu- } \\
\text { cation: } 3 \\
\text { No education: } 11\end{array}$ & $\begin{array}{l}\text { Families with } \\
\text { low EE: } 2\end{array}$ \\
\hline
\end{tabular}

Source: Family Interview 2008.

Table 2

Level of family expressed emotions and frequency of relapse among members living with schizophrenia $(N=31)$

\begin{tabular}{lllll}
\hline \multirow{2}{*}{ Expressed emotion (EE) } & \multicolumn{4}{c}{ Frequency of relapse } \\
& None & Once & More than once & Vagrant \\
\hline Families with High EE & 0 & 13 & 5 & 7 \\
$n=25(80.65 \%)$ & $(0.00 \%)$ & $(41.93 \%)$ & $(16.13 \%)$ & $(22.58 \%)$ \\
Families with Low EE & 5 & 1 & 0 & 0 \\
$n=6(19.35 \%)$ & $(16.13 \%)$ & $(3.23 \%)$ & $(0.00 \%)$ & $0(0.00 \%)$ \\
\hline
\end{tabular}

Fieldwork 2008 


\section{Findings}

- Family member's high or low expressed emotions significantly increase or decrease relapse in the family member living with schizophrenia.

- The gender of the person suffering from schizophrenia determines the level of expressed emotions from family members.

- The level (high or low) of expressed emotions is determined by the socio-demographical characteristics of the family, particularly the head of the household.

\section{Discussion}

This study aimed at assessing expressed emotions of family members as a predictor of the sick member's well being and the course of the disease. It was assumed that care shall be reflected in expressed emotions by family members during interviews and interactive sessions and that high expressed emotions will lead to poor well being in terms of relapses suffered by the sick member, while low expressed emotions will determine the elimination of the sickness or reduction of relapses of schizophrenic episodes. (HOOLEY 1985; HOOLEY \& RICHTERS 1995; ORHAGEN \& ELIA 1991).

The first finding as shown in Table 2 revealed clearly that families with high expressed emotions ( 25 or $80.65 \%$ out of the sampled 31 families) constituted cases of relapses, all 25 or $80.65 \%$ have had a relapse after the first treatment. 13 or $41.93 \%$ had a relapse more than once. And, 7 (22.58\%) are in fact vagrant, that is they are out of family or government control, they now roam the streets. This finding corroborated earlier studies of WEISMAN et al. 1998; WENDEL et al. 2000; MATTEW \& JAN 2007. The problem with families regarding expressed emotions is that the only way they feel their sick members will change their behaviour is through criticism, which actually causes relapse (WENDEL et al. 2000). A person's attitude toward a person, especially when they are very critical, takes a long time to change their way of thinking. High expressed emotion is more likely to cause a relapse than low expressed emotion because of the aggressive verbal criticisms made (WEISMAN et al. 1998).

On the other hand, families with low expressed emotion were six or $19.35 \%$ out of the 31 families sampled. Five of them or $16.13 \%$ have never had a relapse since the first treatment and discharge. Only one or $3.23 \%$ has relapsed. These families feel that the family member does not have control over the sickness and so they sympathize with him/her. This also depends on the information gained about the disease: family members who have more knowledge are more understanding and less critical. These families are more educated and accepting of the illness than those of high expressed emotion. This study confirmed findings of other studies (BREWIN et al. 1991; WEISMAN et al. 1998) that sick members from families with a high level of education usually have little or no relapse cases after treatment. The aforementioned are some reasons for expressed emotion to be low instead of high.

The second finding of this study shows that the gender of the sick member does determine family emotions. Alternatively, it was observed that the sex of the person 
suffering from schizophrenia determines the level of expressed emotions from family members, that is a female sick member attracts low emotions from family members. According to participants, sick female members are labelled more and socially stigmatized. This affects their suitability for marriage and creating a successful family. In Africa, particularly in Nigeria, women who are not married are seen as irresponsible. This determines the mood of family members which is sometimes inadvertently reflected in their speech. A widow head of household expressed this in the following way:

This problem (schizophrenia) is wicked, see my daughter she is no longer sick but because people know her here (in the community) no man wants to come and talk about marriage because they think that if they marry her, the madness will come again, so that is our worry. . . (She then broke down into tears.)

The impression portrayed by this family is that the patient can never be fully 'cured'. This reason of gender determining high emotions towards the sick member, particularly males, cuts across all socio-economic class and educational status in this study. We observed that during the interactive sessions, female sick members were generally urged not to talk by family members making all sorts of nonverbal cues like eye contact. This supports the hypothesis that females are generally pitied and radiate low emotions than male sufferers of schizophrenia. This is an emerging trend and more studies need be conducted in order to establish how true this is.

Furthermore, this study revealed that the level of expressed emotions - whether high or low - can also be determined by socio-demographic characteristics of the family members, particularly the head of the household. During the interaction sessions, it was observed that male heads of households and, in fact, male members of the family show little or no emotions related to the three basic issues raised. They tend to interact with sick members to the extent that we (the research team) do not notice the 'sick' member, except when they talk, their speech is still inconsistent or slurred. In fact, a participant in one of the nine sessions conducted with male heads remarked:

My friends, I have seen life, both in higher school and business, life is designed by God.

So our son (sufferer of schizophrenia) is not different from us, it is just some brain wave and it has stopped 'abi' (is it not true?)

Other family members chorused yes o!

Comments from members show that the CFI revealed that family members' emotions expressed during these interactive sessions significantly determine schizophrenia episodes among members living with the illness. Some of these 'sick' members were able to say why they relapsed, they all blamed family members for their hostility and critical comments. A male 'patient' expressed this as follows:

No condition is permanent. My daddy thinks I am useless, but at least now, I can work (carpentry) and take care of myself, all this talk about being a madman drives me crazy! the 'wahala' (trouble) I got because of my earlier problem (schizophrenia) in this house, is too much, when I think about it, I am . . am . . . am stressed out . . the other time $\left(2^{\text {nd }}\right.$ relapse) the doctor warned you (pointing to his mother) that you are my problem, anyway 'oga' (researcher) will find good work (employment) for me, when I have my own money, these people (family members) will not insult me . . . [hissed]! 
This goes to show that economic factors can also facilitate high emotions expressed by family members. If these are not properly managed, they lead sufferers of schizophrenia to becoming vagrant confirming the argument of OSHISADA 2006 about the upsurge of mental patients roaming the streets of Nigeria towns. It also corroborated earlier studies on economic conditions such as poverty and the course of schizophrenia (LOPEZ et al. 2004; MATTEW \& JAN 2007).

Many of the studies searching into expressed emotions have demonstrated that a high level of expressed emotion from family members correlates positively with schizophrenia relapse (BUTZLAFF \& HoOLEY 1998). The majority of the studies conducted so far are from western countries, which fail to take into account the variation in culture regarding the effect of expressed emotion on patients with schizophrenia. This dearth of research on this topic in Nigeria is due to the longitudinal nature of the studies on family emotions about schizophrenia. However, in this study, despite the cultural differences between countries in the west, and amongst the five ethnicities in Delta State, the results confirmed the findings of earlier studies conducted. In the present study the findings were not in any way determined or affected by the customs, beliefs and traditional practices of the peoples of the state.

\section{Conclusion}

Finally, the thirty-one cases studied were through the observational technique of using a modified Camberwell Family Interview Schedule. This is an interactive session with family members and their schizophrenic member was discharged while the researcher and assistants observed their emotions and general behaviour. It was observed that families or households who make critical comments or display some form of hostility during these interactive sessions also have their 'sick' member relapse more often than those families who show warmth and positive remarks. Therefore, it can be said that some identified socio-demographics of families of people living with schizophrenia determine family emotions, and consequently pose as significant predictors of the course of illness of the schizophrenia sufferer in the house.

Family therapy was suggested to these families. The basic idea here is that the family, not just the individual suffering from schizophrenia, has to alter its behaviour to solve the problem of relapse.

\section{References}

Brewin, C.R., B. Maccarthy, K. Duda \& C.E Vaughn (1991) 'Attribution and Expressed Emotion in the Relatives of the Patients with Schizophrenia', Journal of Abnormal Psychology 100, 546-54.

Bullock, B.M., L. BANK \& B. BurRAston (2002) 'Adult Sibling Expressed Emotion and Fellow Sibling Deviance: A New Piece of Family Process Puzzle', Journal of Family Psychology 16, 307-17. 
Butzlaff, R.L. \& J.M. Hooley (1998) 'Expressed Emotion, and Psychiatric Relapse: A MetaAnalysis', Archives of General Psychiatry 55, 547-52.

Hooley, J.M. (1985) 'Expressed Emotion: A Review of the Critical Literature', Clinical Psychology Review 5, 111-39.

Hooley, J.M. \& J.E. Richters (1995) 'Expressed Emotion: A Developmental Perspective' in D. CiccheTti \& S.L. Toth, eds. Rochester Symposium on Developmental Psychopathology, Emotion Cognition, and Representation, VI:6 (New York: U of Rochester) 134-68.

Human Development Report 2000: Human Rights and Human Development (2000) (New York \& Oxford: Oxford UP for UNDP) retrieved 6 February 2008 from the HDR website, http://hdr.undp.org/en/media/HDR_2000_EN.pdf.

Lopez, S.R., K.N. Hipke, A.J. Plo, J.H. JenKins, M. Karno, C. VAughan \& K.S. Snyder (2004) 'Ethnicity, Expressed Emotion, Attributions, and Course of Schizophrenia: Family Warmth Matters,' Journal of Abnormal Psychology 113, 428-39.

MATTEW, J.S. \& S.G. JAN (2007) 'The Effect of the Quality of Sibling Relationships on the Life Satisfaction of Adults with Schizophrenia', Psychiatric Services 58, 1222-24.

'Nigeria Census Figures 2006' (2007) Federal Republic of Nigeria Official Gazette 94:4 (1 Mar) P.B.52, Annexure A.

Orhagen, T. \& D.G. EliA (1991) 'Expressed Emotion: A Swedish Version of the Camberwell Family Interview', Acta Psychiatrica Scandinavia 84, 5, 466-74.

OshisadA, V. (2006) 'The Upsurge of Mental Patients', The Guardian 23:10 (28 Aug), 65.

RÖSSLER, W., H.-J. SALIZE \& A. RIECHER-RÖSSLER (1996) 'Changing Patterns of Mental Health Care in Germany', International Journal of Law and Psychiatry 19, 3-4 (SummerAutumn), 391-411.

VAughn, C.E., \& J.P. LefF (1976) 'The Measurement of Expressed Emotion in the Families of Psychiatric Patients', British Journal of Social and Clinical Psychology 15, 157-65.

Weisman, A.G., K.H. Nuecherlein, M.J. Goldstein \& K.S. SNyder (1998) 'Expressed Emotion, Attributions, and Schizophrenia Symptoms Dimensions', Journal of Abnormal Psychology 107, 355-59.

Wendel, J.S., D.J. Miklowitz, J.A. Richards \& E.L. George (2000) 'Expressed Emotion, and Attributions in the Relatives of Bipolar Patients: An Analysis of Problem-Solving Interactions', Journal of Abnormal Psychology 109, 792-96.

Worgu, S.O. (2000) 'Hydrocarbon Exploitation Environmental Degradation and Poverty in the Niger Delta Region of Nigeria' (Lund: Urhobo Historical Society, Lund University LUMES Program, January 2000) retrieved 27 Jul 2007 from http://www.waado.org/ Environment/PetrolPolution/EnvEconomics.htm. 